\title{
Pomiędzy pogaństwem a judaizmem. Poganie w synagodze diaspory w okresie panowania rzymskiego, w świetle świadectw literackich i archeologicznych pierwszych wieków po Chrystusie (I-III wieku po Chrystusie)
}

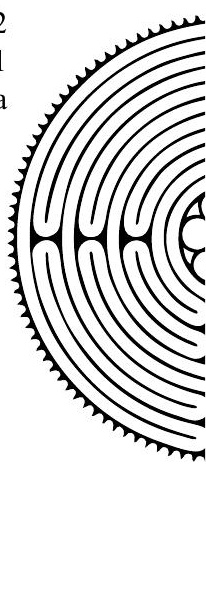

\author{
Maria Miduch \\ Uniwersytet Papieski Jana Pawła II
}

\begin{abstract}
Between Paganism and Judaism. Pagans in Diaspora Synagogues during the Roman Domination in Literary and Archeological Testimonies of the First Centuries $\left(1^{\text {st }}-3^{\text {rd }}\right.$ Centuries AD)
\end{abstract}

The article raises the question of Jewish presence in the pagan world, as well as the impact of the institution of the synagogue on the population not belonging to the Chosen People. While analysing the diaspora of the Roman domination in the Middle East, it is also important to draw attention to the non-Jewish supporters gathered around Jewish communities. Who were these pagans remaining connected to the synagogue? Were they on the way to proselytism? Did they accept only the chosen commands of the Law of Moses, not intending to become full members of the synagogue community? Drawing from literary and archeological sources, the article examines the issues related to the group called the "God-fearers" in the subject literature.

Key words: God-fearers, the Diaspora, proselytism, synagogue

Słowa kluczowe: bojący się Boga, diaspora, prozelityzm, synagoga

Wyjście judaizmu poza krąg społeczeństwa niemal całkowicie oddającego kult jedynemu Bogu zaowocowało spotkaniem żydów z religiami pogańskimi w ich naturalnym środowisku. Było to spotkanie na obcym dla Narodu Wybranego terenie, co wymusiło pewną elastyczność zachowań i form egzystowania. Pierwsze wieki po Chrystusie to czas pod wieloma względami szczególny dla judaizmu i jego wyznawców. Okupacja i polityka rzymska wobec Narodu Wybranego spowodowały 
duże zasilenie istniejących już ośrodków diaspory przez nową falę emigracyjną Żydów. Zburzenie świątyni, a także późniejsza zmiana Jerozolimy w Aelia Capitolina to czynniki, które w wyraźny sposób wpłynęły na rozwój diaspory, mimo że i ona w epoce dominacji rzymskiej na Bliskim Wschodzie przeżywała kryzys ${ }^{1}$. Podejmowane badania nad skupiskami Żydów poza Palestyną często koncentrują się na wewnętrznych strukturach, formach funkcjonowania, czy też teologii obecnej w synagodze „rozproszenia”. Warto jednak zwrócić uwagę na interakcję, w jaką weszli niektórzy poganie z judaizmem, który zaistniał w ich społeczności. Temat ten wydaje się nieczęsto podejmowany na gruncie polskich badań. Niniejsze opracowanie ma na celu zwrócenie uwagi na istniejący problem badawczy i zasygnalizowanie pewnych kwestii, których głębsze rozwinięcie może przysłużyć się zarówno studiom nad judaizmem, jak i nad rozwijającym się w pierwszych wiekach chrześcijaństwem.

\section{Ekskluzywizm religijny starożytnego Izraela}

Starożytny judaizm, mimo swojego wewnętrznego zróżnicowania, jako religia nigdy nie miał charakteru misyjnego. Wybranie przez Boga Abrahama i jego potomków z linii Izaaka oraz związanie ich przymierzem z Bogiem stanowiły podstawę do stworzenia zamkniętej grupy wyznawców Boga Jahwe. Stary Testament, mimo iż dostarcza przykładów pogan włączonych do Narodu Wybranego, w bardzo wyraźny sposób podkreśla ekskluzywny charakter wiary dzieci Patriarchy. Wybór, którego dokonuje Bóg, tkwi u podstaw przeświadczenia dzieci Abrahama o swojej wyjątkowości i odrębności w stosunku do innych ludów. Warto w tym miejscu zauważyć, że pochodzenie etniczne jest tu ściśle związane z wyznawaną religią. Potomkowie Abrahama i Izaaka są złączeni z Bogiem przez akt przymierza i zobowiązania, które z niego wynikają (na przykład obrzezanie).

Jak już wspomniano, w Starym Testamencie można odszukać teksty mówiące o włączeniu do Narodu Wybranego osób, które etnicznie do niego nie należały. Znamy przykład Rachab (Joz 6, 22-25) i jej rodziny czy też Rut Moabitki (Rt). U proroków podeportacyjnych znajdziemy także teksty o charakterze uniwersalistycznym, wspominające o narodach w innym niż wcześniej kontekście, włączające je do zbawczej rzeczywistości mesjańskiej². Ciekawym przykładem poganina związanego z kultem Boga Jahwe jest Syryjczyk, Naaman (2 Krl 5, 1-19), który doświadczywszy uzdrowienia przez proroka jedynego Boga, wraca do swojej ojczyzny z wozem pełnym ziemi, by móc na niej oddawać cześć Jahwe. Jednak ze względu na swoją publiczną funkcję pozostaje on w kontakcie z lokalnymi kultami.

Mimo biblijnych przykładów pogan związanych z religią Izraela, trzeba zaznaczyć, że starożytny judaizm, skupiony wokół świątyni, nie prowadził misji mających na celu włączenie w swoje szeregi nowych wyznawców ${ }^{3}$. Można by rzec, że skupiał

\footnotetext{
${ }^{1}$ Por. P. Johnson, Historia Żydów, Kraków 2010, s. 152-153.

${ }^{2}$ Por. A. Salas, Prorocy. Zwiastuni Boga żywego, Częstochowa 1998, s. 117-119.

${ }_{3}$ Por. J. North, The Development of Religious Pluralism [w:] The Jews among Pagans and Christians in Roman Empire, J. Lieu, J. North, T. Rajak (red.), London-New York 1992, s. 191.
} 
się na sobie, na walce o wewnętrzną spójność i utrzymanie tożsamości etniczno-religijnej Żydów. Historia biblijna obfituje w obrazy ukazujące jak dramatyczna oraz pełna trudnych decyzji była to walka. Wygnanie do Babilonii, a tym samym zanurzenie w obcą, pogańską kulturę, a następnie reforma religijna po powrocie z wygnania, żądająca od Izraelitów osobistych wyrzeczeń, czy też okrutne czasy prześladowań pod dominacją grecką to tylko najbardziej wyraźne przykłady zapisanej na kartach Biblii walki o żydowską tożsamość. Mają one jednak duży wpływ na stosunek Narodu Wybranego do ich pogańskich sąsiadów.

\section{Odmienność judaizmu diaspory}

Nie ulega wątpliwości, że judaizm diaspory okresu przełomu er różniły od judaizmu palestyńskiego warunki, w jakich dzielił codzienność z poganami. Kiedy Żydzi pozostający w swojej ojczyźnie zmagali się z najeźdźcami, wrogą polityką okupanta, ich rodacy z diaspory, w na ogół pokojowej atmosferze, tworzyli struktury pozwalające im zachować własną tożsamość na obczyźnie. Działania judaizmu palestyńskiego ukierunkowane były do wewnątrz. Miały na celu skonsolidowanie wewnętrzne wyznawców przez podkreślenie ich odrębności względem pogan. Tożsamość żydowska była tu budowana na kontraście pomiędzy ludem wybranym a otaczającymi go narodami. Judaizm diaspory, którego wyznawcy nierzadko z własnej woli opuścili ojczyznę w poszukiwaniu lepszej przyszłości ${ }^{4}$, wydaje się ukierunkowywać swoje działania „na zewnątrz” - w celu zapewnienia sobie pełnoprawnego miejsca w pogańskim społeczeństwie ${ }^{5}$. Nie znaczy to jednak, że nie dba on o swoją tożsamość i całkowicie odchodzi od tradycji swoich przodków. Jest jednak bardziej otwarty i nie traktuje obcych kultur jako zagrożenia, ale jako naturalne miejsce swojej bytności ${ }^{6}$.

Wraz ze zburzeniem świątyni w roku 70. oraz nagłym wzrostem liczebności diaspory w II wieku po Chrystusie możemy zauważyć zmianę w kwestii konwersji na judaizm ${ }^{7}$. W diasporze Żydzi musieli od samego początku konfrontować się z poganami, których fascynowała ich religia. Jednak nigdy nie była to rozwinięta akcja misyjna o szeroko zakrojonych działaniach, które miałyby na celu pozyskanie jak największej liczby nowych wyznawców judaizmu ${ }^{8}$.

Zjawisko prozelityzmu, z którym można się spotkać w starożytnym judaizmie, należy więc traktować raczej jako pewien skutek uboczny spotkania Żydów z obcymi kulturami niż jako zamierzony cel. W studium nad identyfikacją grupy pogan

${ }^{4}$ Por. K. Stebnicka, Tożsamość Diaspory. Żydzi w Azji Mniejszej okresu cesarstwa, Warszawa 2011, s. XV.

${ }^{5}$ Istnieje pogląd, który widzi w Septuagincie odpowiedź na politykę rządzącej w Egipcie dynastii Lagidów. W myśl tego twierdzenia grecki przekład Starego Testamentu, a pierwotnie samego Pięcioksięgu, stałby się „prawem obywatelskim” społeczności żydowskiej żyjącej w Aleksandrii. Por. S. Jędrzejewski, Biblia i judaizm, Kraków 2007, s. 16.

${ }^{6}$ Por. K. Stebnicka, Tożsamość..., s. 21.

${ }^{7}$ Por. M. Goodman, Jewish Proselytizing in the First Century [w:] The Jews among Pogans..., s. 74.

${ }^{8}$ Por. D. Rokéah, Ancient Jewish Proselytism in Theory and in Practice, „Theologisches Zeitschrift” 1996, vol. 52, nr 3, s. 208. 
pozostającej w relacjach z synagogą nie można jednak zupełnie pominąć istnienia prozelitów w żydowskich społecznościach.

Judaizm różniący się pod wieloma względami od starożytnych religii Bliskiego Wschodu, stający niejako w opozycji do obcej kultury ${ }^{9}$, jednak umiejący z niej także czerpać ${ }^{10}$, wzbudzał zainteresowanie w otwartym na sferę sacrum starożytnym świecie pogańskim. Wiara w jednego Boga, który wybiera jeden z narodów i czyni go swoją szczególną własnością, właśnie ze względu na swój ekskluzywizm musiała budzić zainteresowanie. Owa ciekawość nie zawsze jednak prowadziła do pełnej konwersji i całkowitego przylgnięcia do żydowskiej wspólnoty. Jednakże nie można zaprzeczyć, że judaizm miał swoich sympatyków w świecie pogańskim ${ }^{11}$. Wzmianki o zainteresowanych religią żydowską pochodzących z różnych narodów można odnaleźć w Dziejach Apostolskich. Sprzyja temu fabuła księgi. Żydowscy apostołowie udają się do świata pogan by głosić Dobrą Nowinę i tu natrafiają na środowisko zaznajomione z ich rodzimą kulturą religijną. Spotkanie świata żydowskiego i pogańskiego nastąpiło bowiem już wcześniej przez diasporę.

\section{Literackie świadectwa o poganach czczących żydowskiego Boga}

Pochylając się nad literackimi przekazami obecności pogan w diasporze przełomu er, nie sposób pominąc Dziejów Apostolskich. Należy jednak zadać sobie pytanie, czy nowotestamentalne świadectwa o poganach oddających cześć żydowskiemu Bogu można traktować jako wiarygodny materiał historyczny odnoszący się do zjawiska istnienia „theosebeis” w tym okresie. Trudno bowiem nie zauważyć, że to teologia, a nie oddanie faktów historycznych, stała się elementem kształtującym treść owej księgi. Społeczne zjawiska przywoływane przez autora nie mają bowiem służyć jako materiał analiz socjologicznych czytelnika, a raczej wprowadzać w prezentowaną przez niego teologię. Świadectwa znalezione w Nowym Testamencie są niezwykle cenne dla teologicznej interpretacji zagadnienia pogan czczących żydowskiego Boga, jednak to stanowi już kolejny krok w analizie owego zjawiska. W niniejszym opracowaniu zostaną one jedynie wspomniane, jednak teologia tkwiąca u genezy ich obecności w Nowym Testamencie domaga się osobnego opracowania.

Już na samym początku Dziejów Apostolskich czytamy o dworzaninie królowej etiopskiej, który przybywa do Jerozolimy oddać cześć żydowskiemu Bogu. Podczas studiów nad Księgą Izajasza spotyka go Filip i udziela mu chrztu (por. Dz 8, 26-38). Ów Etiopczyk jest właśnie przykładem poganina, który żywo interesuje się judaizmem i darzy go szczególnym sentymentem. Udaje się on nawet w długą drogę, by osobiście modlić się w Jerozolimie. Podobnym przykładem może być wspomniany w księdze Korneliusz, rzymski żołnierz oddający cześć Bogu razem z całą swoją

\footnotetext{
${ }^{9}$ Por. J. Ciecieląg, Żydzi w okresie Drugiej Światyni 538 przed Chr. - 70 po Chr., Kraków 2011, s. 131-134.

${ }^{10}$ Por. T. Jelonek, Kultura grecka a Stary Testament, Kraków 2011, s. 5-6.

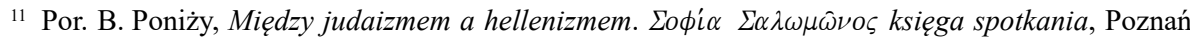
2013, s. 50-51.
} 
rodziną, który słuchał nauczania Szymona Piotra (por. Dz 10-33). Nie jest on obrzezanym prozelitą, lecz jedynie poganinem, którego pociąga wiara w jedynego Boga.

Szczególną kategorią słuchaczy apostolskiego nauczania są skupiający się w gminach żydowskich poganie. Obecność obcych ludów przy synagogach, rozproszonych po całym ówczesnym cywilizowanym świecie, nie jest niczym zaskakującym dla autora księgi. Relacjonując mowę Jakuba podczas Soboru Jerozolimskiego, sugeruje on uczestnictwo pogan w słuchaniu szabatowego wyjaśniania Prawa Mojżeszowego (por. Dz 15, 21). Dzieje Apostolskie wspominają o „bojącej się Boga” Lidii, bogatej kobiecie, która przysłuchiwała się nauczaniu Pawła w miejscu żydowskich modlitw (por. Dz 16, 13-14). Nie jest ona Żydówką, lecz mieszkanką miasta Tiatyra. Chrześcijańska tradycja widzi w niej pierwszą świętą Europejkę. Jednak zanim została ona chrześcijanką, przychodząc na miejsce żydowskich spotkań i słuchając żydowskich nauczycieli, w wyraźny sposób pokazywała swoją sympatię i zainteresowanie judaizmem. Obecność „bojących się Boga” w synagodze zauważa także Paweł nauczający w szabat w Antiochii (por. Dz 13).

Nowotestamentalne świadectwa o poganach, którzy oddawali cześć jedynemu Bogu i wyraźnie sympatyzowali z Żydami, przez niektórych uczonych bywają traktowane jedynie jako teologiczny zabieg autorów biblijnych, mający na celu wskazanie pomostu między chrześcijaństwem a pogaństwem. Dawni politeiści, którzy przyjęli wiarę $\mathrm{w}$ jedynego Boga, ale nie dokonali pełnej konwersji na judaizm, stanowiliby doskonały materiał na pierwszych chrześcijan pochodzących z narodów ${ }^{12}$. Uczynili oni bowiem już pierwszy krok w stronę poznania prawdy i przybliżyli się do jedynego Boga, więc kolejny krok, którym było rozpoznanie w żydowskim mesjaszu odkupiciela całej ludzkości, nie był już tak szokujący ${ }^{13}$. Skupiając się jedynie na teologicznej warstwie Dziejów Apostolskich, należałoby odrzucić zawarty w nich materiał jako nieużyteczny dla badań historycznych w kwestii istnienia grupy pogan pretendującej do miana „bojących się Boga” i zbierającej się wokół starożytnych ośrodków judaizmu w diasporze. Idąc dalej tym tokiem myślenia, można by nawet powątpiewać $\mathrm{w}$ znaczenie grupy pogan zainteresowanych judaizmem i odrzucić określenie „bojący się Boga” jako termin techniczny oraz powszechnie znany i używany $w$ odniesieniu do tych niepełnych prozelitów ${ }^{14}$. Jednak warto mieć na uwadze, że świadectwa nowotestamentalne nie są jedynymi źródłami, w których znajdujemy obecność pogańskich sympatyków judaizmu. Cennym skarbcem wiadomości na interesujący nas temat są pozachrześcijańskie przekazy zarówno autorstwa żydowskiego, jak i rzymskiego. Wartość tych źródeł jest szczególna ze względu na ich historyczny charakter.

${ }_{12}$ Por. J.M. Lieu, The Race of the God-Fearers, ,Journal of Theological Studies” 1995, vol. 46, nr 2, s. 483.

${ }_{13}$ Por. J.M. Lieu, Do God-Fearers make good Christians? [w:] Crossingthe Boundaries. Essays in Biblical Interpretation in Hounour M.D. Goulder, S.E. Porter, P. Joyce, J.D. Orton (red.), Leiden-New York-Köln 1994, s. 329-345.

${ }^{14}$ Por. R.S. McLennan, A.T. Kraabel, The God-Fearers - a Literary and Theological Invention, „Biblical Archeology Review” 1986, vol. 12, nr 5, s. 48. 
O wyznawcach żydowskiego Boga pochodzących z ludów pogańskich wspomina Józef Flawiusz w Dawnych dziejach Izraela, opisując bogactwo Świątyni w Jerozolimie. Pisze:

Niech się nikt nie dziwi, że tak wielkie bogactwa były zgromadzone w naszej świątyni, boć przecież słali je tam od dawien dawna wszyscy Judejczycy i wyznawcy naszego Boga z całego świata, zarówno z Azji, jak i Europy (Ant. XIV, 110).

Ten sam autor wskazuje również na żonę Nerona, Poppeę, jako na wielką sympatyczkę religii żydowskiej i Narodu Wybranego. Wspomina o tym przy okazji relacjonowania kwestii muru świątynnego, który król Agryppa kazał, ku sprzeciwowi Żydów, zburzyć. „Neron [...] pozwolił postawić tę budowlę, chcąc dogodzić swojej żonie Poppei, która, że była bogobojna (theosebes), wstawiała się za Żydami" (Ant. XX, 195). Sympatię żony cezara do Żydów zdają się potwierdzać hebrajsko-aramejskie graffiti znalezione $\mathrm{w}$ jej posiadłości ${ }^{15}$.

$\mathrm{Na}$ szczególną uwagę zasługuje wzmianka, którą odnaleźć można u historyka rzymskiego, Swetoniusza. Pisząc o wygnaniu z Rzymu Żydów przez cesarza Tyberiusza, zaznacza, że wypędzeni zostali nie sami Żydzi, ale też ci, którzy pewnymi zwyczajami upodobnili się do nich ${ }^{16}$.

Rzymscy sympatycy judaizmu nie uniknęli wyśmiewania ze swojej pobożności. Potwierdzają to niektóre satyry Juwenalisa. Mowa tam zarówno o tych, którzy przychylnie odnosili się do pewnych żydowskich zwyczajów, jak i o tych, którzy dokonali pełnej konwersji. Autor naśmiewa się tu z dzieci rzymskich sympatyków judaizmu, które to w swej gorliwości zachowywania żydowskich zwyczajów przewyższyły swoich ojców ${ }^{17}$.

Świadectwa literackie wywodzące się z kręgu rzymskiego wydają się niezwykle cenne dla badań nad grupą pogan, która w szczególny sposób weszła w interakcję z Narodem Wybranym. Mimo że brak im współcześnie cenionej obiektywności historycznej, to ich głównym celem było opisanie istniejącego w społeczeństwie zjawiska. Nie brak tu oczywiście stronniczości i ukrytych intencji, jednak nie można posądzić ich autorów o przedstawienie całkowicie wyimaginowanej grupy w opisywanych przez nich realiach. Poganie pozostający w relacji do wyznawców judaizmu i ich Boga musieli istnieć w starożytnym społeczeństwie, a ich obecność była zauważalna.

${ }^{15}$ Por. T. Grüll, L. Benke, A Hebrew/Aramaic graffito and Poppaea's alleged Jewish sympathy, „Journal of Jewish Studies” 2011, vol. 62, nr 1.

${ }^{16}$ Por. Suetonius, De vitae Caesarum, Tib. 36. Za: Swetoniusz, Żywoty cezarów, t. 2. thum. J. Niemirska-Pliszczyńska, Wrocław-Warszawa 2004.

${ }^{17}$ Por. Juvenalis, Satire, 14. Za: T.M. Finn, The God-Fearers Reconsidered, „The Catholic Biblical Quarterly"1985, vol. 47, nr 1, s. 81. 


\section{4. Świadectwa archeologiczne o poganach czczących żydowskiego Boga}

Czy na podstawie świadectw literackich można więc wyodrębnić osobną kategorię pogan, którzy pozostawali w pewnej relacji do judaizmu, jednak w pełni go nie wyznawali? Czy termin theosebeis można traktować jako techniczne określenie tej właśnie grupy pogan? Do lat osiemdziesiątych XX wieku opinia naukowa zdawała się jednoznacznie stwierdzać, że „bojący się Boga” to nic innego, jak określenie osoby lub grupy osób odznaczającej się wyjątkową pobożnością, tym samym traktując ten tytuł jako podkreślenie szczególnego oddania się sprawom Bożym ${ }^{18}$. Termin ten odnosiłby się zresztą nie tylko do osób związanych ze środowiskiem żydowskim, lecz także do ogólnie pojętego środowiska religijnego. Koncepcja ta zresztą nadal ma swoich zwolenników ${ }^{19}$. W roku 1987 opublikowano odkryte 11 lat wcześniej inskrypcje bloku z Afrodisias ${ }^{20}$, które przyczyniły się do poszerzenia perspektywy badań nad obecnością Żydów w Azji Mniejszej oraz kultu jedynego Boga w mieście poświęconym bogini Afrodycie, a tym samym klasyfikacji „bojących się Boga"21.

Znaleziono tam dwie listy imion oddzielone od siebie przerwą. Pierwszą grupę stanowią imiona w większości żydowskie. Jest ich 55. Druga lista to imiona o pochodzeniu pozażydowskim, których odnotowano 52. Została ona wprowadzona przez greckie: $\kappa \alpha \iota$ ö $\sigma o \iota ~ \theta \epsilon o \sigma \epsilon \beta \epsilon \iota \varsigma$. Nie wiadomo jednak, czy przed pierwszą z grup nie

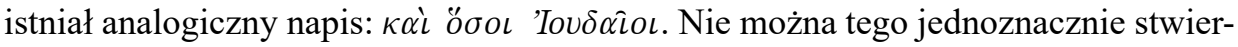
dzić ze względu na niezachowaną pierwszą linię tekstu ${ }^{22}$. Gdyby tak jednak było, zawęziłoby to znacznie pole identyfikacji grupy theosebeis. Brak formuły wprowadzającej przed pierwszą kolumną imion nie jest jednak argumentem przemawiającym za uznaniem osób noszących imiona zapisane w drugiej kolumnie za żydowskich członków synagogi, których pobożność została podkreślona przez nadanie im miana „bojących się Boga”.

Pewną wskazówką w interpretacji inskrypcji z bloku w Afrodisias może być graficzne rozmieszczenie obu list imion. Wyraźne rozdzielenie na dwie kolumny oraz nadany tytuł theosebeis poprzedzający wykaz imion tylko greckiego pochodzenia pozwala na wysunięcie hipotezy o istnieniu przy synagodze osobnej grupy pogan, którzy nie weszli na drogę prozelityzmu, lecz okazywali sympatię judaizmowi. Wyrycie ich greckich imion w odstępie od żydowskich może wskazywać na pewną trwałość ich oddzielenia. Nie byli oni na drodze do pełnego włączenia w judaizm, a co się z tym wiąże - trwałego włączenia do społeczności żydowskiej diaspory. Pozostawali

${ }^{18}$ Por. M. Wilcox, The God-Fearers in Acts - a Reconsideration, „Journal for the Study of the New Testament" 1981, vol. 13 nr 4, s. 115.

${ }_{19}$ Por. S. Mitchell, Further Thoughts on the Cult of Theos Hypsistos [w:] One God: Pogan Monotheism in the Roman Empire, S. Mitchell (red.), Cambridge 2010, s. 189-196.

${ }^{20}$ Dziś południowo-zachodnia Turcja.

${ }^{21}$ Por. R.F. Tannenbaum, Jews and God-Fearers in the Holy City of Aphrodite, „Biblical Archeology Review" 1996, vol. 12, nr 5, s. 35.

${ }^{22}$ Por. K. Stebnicka, Tożsamość..., s. 71. 
nieco z boku, a jednak w pewnej łączności z synagogą. Stanowili grupę połowicznych prozelitów, których droga niekoniecznie wiodła do pełnej konwersjii ${ }^{23}$.

Robert F. Tannenbaum, mając wgląd do notatek z wykopalisk Joyce'a M. Reynoldsa jeszcze przed ich oficjalną publikacją, zauważa, że niektóre spośród imion pojawiających się w kolumnie opatrzonej tytułem theosebeis powtarzają się w spisie radnych miejskich Afrodisias. Fakt ten stanowi niezwykle pomocną wskazówkę przy identyfikacji owych „bojących się Boga”. Jako oficjalni przedstawiciele miasta byli oni więc włączeni w kult bogini mu patronującej. Każde zebranie rady miejskiej rozpoczynały bowiem obrzędy liturgiczne ku czci bóstwa bądź bóstw, do których mieszkańcy żywili szczególną pobożność. Udział w kulcie Afrodyty jest kolejnym dowodem przemawiającym za tym, że theosebeis stanowili grupę spoza żydowskiej wspólnoty, która tylko w jakiś ograniczony sposób czciła Boga Jahwe ${ }^{24}$.

Wśród interpretatorów inskrypcji są też osoby widzące $\mathrm{w}$ greckich imionach theosebeis pogan, którzy w swej wspaniałomyślności postanowili dołożyć się do żydowskiej fundacji, co tłumaczy wyrycie ich imion na bloku. Oddzielenie imion wskazywałoby na pewną separację, która - mimo życzliwych stosunków sąsiedzkich - istniała pomiędzy Narodem Wybranym a poganami. Miano „bojących się Boga” nie byłoby tu terminem technicznym określającym grupę pozostającą w relacji do środowiska synagogi, lecz jedynie pełnym uznania podkreśleniem ich zasług dla wspólnoty żydowskiej ${ }^{25}$.

Co szczególnie interesujące, lista imion oznaczonych jako theosebeis zawiera tylko imiona greckie. Brak w niej imion hebrajskiego pochodzenia, tymczasem pierwsza z list, odnosząca się prawdopodobnie do pełnoprawnych członków synagogi, składa się niemal wyłącznie z imion typowo żydowskich. Jednak i tu występują imiona greckie, co zdaje się potwierdzać jedynie fakt, że to nie przynależność etniczna decydowała o miejscu, w którym były one zapisane, a raczej przynależność religijna. Prozelici pochodzenia pogańskiego zostali bowiem umieszczeni pomiędzy Żydami.

Dodatkowe światło na klasyfikację „bojących się Boga” rzuca kolejne odkrycie w Afrodisias. Znajdujący się w tamtejszym teatrze napis, który wskazuje odpowiednie miejsca poszczególnym grupom społecznym, głosi: $\sim E \beta \rho \alpha i ́ \omega v \tau \omega / v \tau \varepsilon \lambda \varepsilon i ́ \omega v$, a więc dla „całkowitych Hebrajczyków”, jednoznacznie sugerując, że musiała istnieć też grupa, która była „niecałkowitymi Hebrajczykami”. Bardzo prawdopodobne, że dotyczyło to właśnie theosebeis ${ }^{26}$. Ich sympatia do religii żydowskiej była zauważalna nie tylko w kręgach synagogalnych, ale też na szerszym forum życia społecznego. Jednak i tam dostrzegano ich odmienność od Żydów, zwracając uwagę na ich umiejscowienie pośrodku drogi prowadzącej do pełnej konwersji.

\footnotetext{
${ }^{23}$ Por. R.S. MacLennan, A.T. Kraabel, The God-Fearers..., s. 47.

${ }^{24}$ Por. R.F. Tannenbaum, Jews..., s. 57.

${ }_{25}$ Por. M.P. Bonz, The Jewish Donor Inscriptions from Aphrodisias: Are They both Third Century, and who are Theosebeis?, „Harvard Studies in Classical Philology” 1994, vol. 96, nr 4, s. 281-299.

${ }^{26}$ Por. L.H. Feldman, The Omnipresence of the God-Fearers, „Biblical Archeology Review” 1998, vol. 12 , nr 5, s. 63 .
} 
Owoce wykopalisk z Afrodisias, pochodzących z przełomu II i III wieku po Chrystusie $^{27}$, ukazują złożoną rzeczywistość judaizmu diaspory. Można zauważyć, że oddzielenie religii żydowskiej od świata pogańskiego nie jest tam aż tak rygorystyczne. Osoby pozostające w pogańskiej codzienności w jakiś sposób czują się zachęcone do uczestnictwa w życiu religijnym swoich żydowskich sąsiadów. Żydzi natomiast dopuszczają ich do pewnych form swojej pobożności, nie stawiając zbyt wysokich wymagań ${ }^{28}$.

Ciekawe świadectwo o istnieniu grupy pogan żywo związanych z synagogą, ale pozostających w pewnej autonomii do Żydów, stanowią teksty pochodzące z przełomu I i II wieku po Chrystusie, znalezione w Pantikapaion. To dokumenty odnoszące się do wyzwolenia niewolników. Według ustalonych reguł na końcu dokumentu widnieje nazwa instytucji, która potwierdza nowy status społeczny byłego niewolnika. W tym przypadku jest to „wspólnota Żydów i czczących Boga”29. Takie określenie zdaje się w jednoznaczny sposób wskazywać na niejednolitość wspólnoty skupionej wokół synagogi w Pantikapaion. Widać tu grupę Żydów i grupę czczących Boga a więc pogan, którzy oddają cześć Jahwe ${ }^{30}$. Dokument ten został napisany w synagodze, dlatego nie ma potrzeby uszczegóławiania w nim, o jakiego z bogów chodzi. Nie rozstrzyga to oczywiście kwestii, czy owi „czczący Boga” czcili, tak jak Żydzi, tylko jednego Boga, czy też czynili go jednym $z$ wielu w panteonie swoich bóstw.

O pogańskim sentymencie do żydowskich zwyczajów bez pełnej konwersji mogą świadczyć zachowane z I wieku po Chrystusie dokumenty, które wyszły spod ręki rzymskiego administratora w Egipcie. Znaleźć w nich można imię Sabathion, przy czym wymienia się też imiona rodziców i dziadków, które w żaden sposób nie są powiązane z żydowską religią. Imię to prawdopodobnie nadawane było dzieciom urodzonym w szabat $\mathrm{w}$ rodzinach pogańskich, które w jakiejś części zachowywały żydowskie zwyczaje, w tym przestrzegały szabatu ${ }^{31}$.

Przywołane tu świadectwa mówiące o poganach pozostających w związku z synagogą nie są jedyne. Starożytne źródła wielokrotnie wspominają o ich istnieniu. Nie można więc zaprzeczyć, że istniała grupa „nie-Żydów”, którzy przejawiali zainteresowanie religią żydowską bądź jej poszczególnymi elementami. Nie zawsze oznaczało to jednak całkowite odejście od pogańskich kultów na rzecz liturgii synagogalnej. Czasem mogłaby być to jedna $\mathrm{z}$ wielu religijnych dróg, jakimi podążali ${ }^{32}$. Podobnie jak judaizm diaspory odznaczał się dużym zróżnicowaniem, tak i grupy stanowiące jego satelity z pewnością różniły się od siebie. Stopień zaangażowania się pogan w kult Jahwe zapewne nie był taki sam w całej diasporze w czasie dominacji rzymskiej ${ }^{33}$. Czy więc można owej grupie przypisać jedną nazwę? Czy też jej

${ }^{27}$ Por. R.F. Tannenbaum, Jews..., s. 55.

${ }^{28}$ Por. ibidem, s. 57.

${ }^{29}$ Por. K. Stebnicka, Tożsamość..., s. 72-73.

${ }^{30}$ Por. S. Mitchell, Further thoughts..., s. 193-194.

${ }^{31}$ Por. L.H. Feldman, The Omnipresence..., s. 63.

32 Por. R.F. Tannenbaum, Jews..., s. 57.

${ }^{33}$ Por. P. Fiałkowski, Judaizanci [w:] Polski stownik judaistyczny, t. 2, Z. Borzymińska, R. Żebrowski (red.), Warszawa 2003, s. 714-715; R. Żebrowski, Goj [w:] Polski słownik..., t. 1, s. 495. 
nazewnictwo było lokalne, uzależnione od środowiska, z jakiego wywodzili się pogańscy sympatycy judaizmu, lub od specyfiki synagogi, do której chcieli dołączyć?

Pisane świadectwa odległych wieków, jakie przetrwały do naszych czasów, które wyszły zarówno spod ręki żydów, chrześcijan, jak i pogan, nie pozostawiają wątpliwości co do istnienia skupionych wokół wspólnot żydowskich sympatyków ich religii i kultury. Pozostaje jednak kwestią sporną, czy istniał jeden termin używany na określenie owego zjawiska i wskazanie tych niepełnych prozelitów, jak zwykło się ich określać. Czy można przyjąć, że powszechnie nazywano ich „bojącymi się Boga”?

W tym miejscu należy przywołać wspomniane już hipotezy o teologicznej roli, jaką według niektórych uczonych św. Łukasz nadał poganom sympatyzującym z judaizmem, zbytnio akcentując rolę owych grup skupionych wokół synagog ${ }^{34}$. Wiemy jednak, że Dzieje Apostolskie nie są jedynym świadectwem pogańskiej sympatii do judaizmu. Warto zauważyć, że mimo istnienia zróżnicowania w terminach określających ową specyficzną grupę pogan, wszystkie one odnoszą się do czci i bojaźni wobec Boga, sugerują pobożność określanych nimi osób. W Dziejach Apostolskich spotykamy bowiem zarówno theosebeis, jak i phobomenoi. Juwenalis z kolei mówi o metuentes ${ }^{35}$. Flawiusz, pisząc o bogactwach napływających do świątyni, wspomina o sebomenon ton theon. Talmud w swoich tekstach również odwołuje się do tej złożonej rzeczywistości pogan czczących Boga Jahwe. Nazywa ich „bojącymi się Niebios”. Można więc zauważyć, że słowo „Bóg” zostało tu zastąpione terminem „niebiosa". Jednak w tym wypadku można potraktować go jako synonim Boga. Również midrasze pochodzące z pierwszych wieków używają tego określenia ${ }^{36}$.

Pochylając się nad starożytnymi tekstami oraz inskrypcjami, należy jednak zachować niezwykłą czujność i delikatność w traktowaniu tego typu terminów jako technicznej nazwy ułatwiającej identyfikację grupy sympatyków judaizmu. Terminy te, występujące przy pojedynczych nazwach własnych, w szczególności na inskrypcjach nagrobnych, mogą bowiem sugerować pobożność danej osoby i jej oddanie sprawom sacrum, nie zaś przynależność do szczególnej grupy okołosynagogalnej. Nie muszą być one w ogóle połączone ze środowiskiem żydowskim, lecz pochodzić z kręgów pogańskich i odnosić czytającego do kultu bożków ${ }^{37}$.

\section{Poganie w Synagodze - podsumowanie}

Przywołane tutaj odkrycia archeologiczne pozwalają stwierdzić, że w pewnych środowiskach termin theosebeis przypisany był do konkretnej grupy pogan pozostającej w relacjach z synagogą. Jakie dokładnie były to relacje, trudno określić. Determinatyw „bojący się Boga” może wskazywać na pewne powiązania kultyczne. Żydowskich członków synagog i ich pogańskich sąsiadów zaliczanych do theosebeis łączyłaby cześć oddawana wspólnemu Bogu i co najmniej częściowy udział w liturgii

\footnotetext{
34 Por. R.S. MacLennan, A.T. Kraabel, The God-Fearers..., s. 47-48.

35 Por. K. Stebnicka, Tożsamość..., s. 70.

36 Por. L.H. Feldman, The Omnipresence..., s. 61-62.

37 Por. K. Stebnicka, Tożsamość..., s. 73.
} 
synagogalnej. Samo zjawisko pogan uczestniczących w życiu żydowskiej diaspory wydaje się ciągle do końca niewyjaśnione. Nie ma podstaw, by twierdzić, że było ono sformalizowane i we wszystkich synagogach wyglądało podobnie. Stopień przylgnięcia do religii żydowskiej również nie musiał być ten sam dla wszystkich „czczących jedynego Boga". Takie zróżnicowanie wydaje się naturalnym stanem rzeczy $\mathrm{w}$ obliczu wewnętrznej różnorodności judaizmu ${ }^{38}$. Judaizm - także ten w diasporze - przechodził wiele etapów, w jego obrębie kształtowały się różne nurty. Taka różnorodność, a także zdolność do wewnętrznej ewolucji sprzyjały rozwojowi pogańskiego środowiska około synagogalnego.

Fenomen pogan przyłączających się do wyznawców Boga Izraela wydaje się ciągle pozostawać niezbadany. Nie można jednak zupełnie zbagatelizować owego zjawiska i zapchnąć go na margines studiów nad judaizmem Żydów rozproszonych wśród obcych ludów. Przywoływane tu odkrycia archeologiczne świadczą o powszechności istnienia grupy pogan związanych z synagogą oraz ich szczególnym miejscu zarówno w przestrzeni żydowskiej, jak i tej pogańskiej. Ich sympatia względem kultu Boga Izraela nie pozostawała sprawą zauważalną jedynie w środowisku synagogalnym.

Badania i studia nad istnieniem pogańskiego środowiska, powiązanego na gruncie religijnym ze środowiskiem żydowskim, ukazują złożoną sytuację judaizmu diaspory i potwierdzają od strony historycznej Łukaszowy przekaz o skupionych wokół żydowskich wspólnot osobach pochodzących z innych narodów, a sympatyzujących $\mathrm{z}$ religią mojżeszową. Odkrycia owe rzutują także na postrzeganie judaizmu diaspory, który zanurzony w obce środowisko, musiał wejść w reakcję z pogańskimi sąsiadami.

\section{Bibliografia}

Bonz M.P., The Jewish Donor Inscriptions from Aphrodisias: Are They both Third Century, and who are Theosebeis?, „Harvard Studies in Classical Philology” 1994, vol. 96, nr 4, s. 281-299.

Chrostowski W., Asyryjska diaspora Izraelitów i inne studia, Warszawa 2003.

Ciecieląg J., Żydzi w okresie Drugiej Świątyni 538 przed Chr. - 70 po Chr., Kraków 2011.

Feldman L.H., The Omnipresence of the God-Fearers, „Biblical Archeology Review” 1998, vol. 12 , nr 5, s. 59-68.

Finn T.M., The God-Fearers Reconsidered, „The Catholic Biblical Quarterly” 1985, vol. 47, nr 1, s. $75-84$.

Goodman M., Jewish Proselytizing in the First Century [w:] The Jews among Pagans and Christians in Roman Empire, J. Lieu, J. North, T. Rajak (red.), London-New York 1992.

Grüll T., Benke L., A Hebrew/Aramaic graffito and Poppaea's alleged Jewish sympathy, „Journal of Jewish Studies" 2011, vol. 62, nr 1, s. 37-55.

Jelonek T., Kultura grecka a Stary Testament, Kraków 2011.

Jędrzejewski S., Biblia i judaizm, Kraków 2007.

Johnson P., Historia Żydów, Kraków 2010.

${ }^{38}$ Por. S. Jędrzejewski, Biblia..., s. 5. 
Lieu J.M., Do God-Fearers make good Christians? [w:] Crossing the Boundaries. Essays in Biblical Interpretation in Hounour M.D. Goulder, S.E. Porter, P. Joyce, J.D. Orton (red.), LeidenNew York-Köln 1994, s. 329-345.

Lieu J.M., The Race of the God-Fearers, ,Journal of Theological Studies” 1995, vol. 46, nr 2.

McLennan R.S., Kraabel A.T., The God-Fearers - a Literary and Theological Invention, „Biblical Archeology Review"1986, vol. 12, nr 5, s. 46-53.

Mitchell S., Further Thoughts on the Cult of Theos Hypsistos [w:] One God: Pogan Monotheism in the Roman Empire, S. Mitchell (red.), Cambridge 2010, s. 167-208.

North J., The Development of Religious Pluralism [w:] The Jews among Pagans and Christians in Roman Empire, J. Lieu, J. North, T. Rajak (red.), London-New York 1992.

Polski słownik judaistyczny, t. 1, 2, Z. Borzymińska, R. Żebrowski (red.), Warszawa 2003.

Poniży B., Między judaizmem a hellenizmem. $\Sigma o \phi^{\prime} \alpha \Sigma \alpha \lambda \omega \mu \hat{\omega} \nu o \varsigma$ księga spotkania, Poznań 2013.

Rokéah D., Ancient Jewish Proselytism in Theory and in Practice, „Theologisches Zeitschrift” 1996, vol. 52, nr 3, s. 206-224.

Salas A., Prorocy. Zwiastuni Boga żywego, Częstochowa 1998.

Stebnicka K., Tożsamość Diaspory. Żydzi w Azji Mniejszej okresu Cesarstwa, Warszawa 2011.

Swetoniusz, Żywoty cezarów, t. 2, thum. J. Niemirska-Pliszczyńska, Wrocław-Warszawa 2004.

Tannenbaum R.F., Jews and God-Fearers in the Holy City of Aphrodite, „Biblical Archeological Review" 1986, vol. 12, nr 5, s. 46-53.

Theologisches Wörterbuch zum Alten Testament, t. 6, H.J. Fabry, H. Ringgra (red.), Stuttgart-Berlin-Köln 1989.

Wilcox M., The God-Fearers in Acts - a Reconsideration, „Journal for the Study of the New Testament" 1981, vol. 13, nr 4, s. 102-122. 